\title{
Using Google Classroom to Increase Student Motivation in a Pandemic Period
}

\author{
Warih Setya Wardani \\ SD Negeri 1 Purwanegara \\ lituhayuazzahra@gmail.com
}

\section{Article History}

accepted 01/11/2020

approved 08/11/2020

published 15/11/2020

\begin{abstract}
The purpose of this study was to increase the learning motivation of students in class VI Theme 5. This research is a classroom action research (CAR) which is carried out in three cycles, each cycle consisting of planning, implementation, observation, and reflection stages. The subjects of this study were 37 students of class VI SD Negeri 1 Purwanegara in the 2020/2021 academic year. Data collection techniques using observation and questionnaires. Data analysis includes data reduction, data presentation, and drawing conclusions. Research shows that the use of Google Classroom in online learning during a pandemic can increase student learning motivation Theme 5 class VI SD Negeri 1 Purwanegara academic year 2020/2021 as evidenced by the percentage increase in learning motivation in cycle I by $65 \%$ to $84 \%$ in cycle II and increasing in cycle III by $95 \%$.
\end{abstract}

Keywords: Google Classroom, Pandemic Period, Grade VI Students

\section{Abstrak}

Tujuan penelitian ini adalah meningkatkan motivasi belajar siswa kelas VI Tema 5. Penelitian ini merupakan penelitian tindakan kelas (PTK) yang dilaksanakan dalam tiga siklus, setiap siklus terdiri dari tahap perencanaan, pelaksanaan, observasi, dan refleksi. Subjek penelitian ini adalah peserta didik kelas VI SD Negeri 1 Purwanegara tahun pelajaran 2020/2021 yang berjumlah 37 peserta didik. Teknik pengumpulan data menggunakan observasi dan angket. Analisis data meliputi reduksi data, penyajian data, dan penarikan kesimpulan. Penelitian menunjukkan bahwa penggunaan Google Classroom pada pembelajaran daring di masa pandemi dapat meningkatkan motivasi belajar siswa Tema 5 kelas VI SD Negeri 1 Purwanegara tahun pelajaran 2020/2021 yang dibuktikan dengan persentase peningkatan motivasi belajar pada siklus I sebesar $65 \%$ menjadi $84 \%$ pada siklus II dan semakin meningkat pada siklus III sebesar 95\%.

Kata kunci: Google Classroom, Masa Pandemi, Siswa Kelas VI

Social, Humanities, and Education Studies (SHEs): Conference Series https://jurnal.uns.ac.id/shes 


\section{PENDAHULUAN}

Saat ini COVID-19 menjadi pembicaraan yang hangat di belahan bumi manapun. Virus ini menular sangat cepat dan telah menyebar hampir ke semua negara, termasuk Indonesia. Sehingga WHO pada tanggal 11 Maret 2020 menetapkan wabah ini sebagai pandemi global. Beberapa pemerintah daerah menerapkan kebijakan untuk meliburkan siswa dan mulai menerapkan metode belajar dengan sistem daring (dalam jaringan) atau online. Tetapi hal tersebut menimbulkan permasalahan terkait pembelajaran di beberapa sekolah. Sekolah-sekolah tersebut tidak siap dengan sistem pembelajaran daring, dimana membutuhkan media pembelajaran seperti handphone, laptop, komputer, atau internet.

Berdasarkan hasil observasi yang dilakukan penulis masih ada permasalahan mengenai motivasi belajar siswa dalam pembelajaran daring. Beberapa penyebab masalah yaitu siswa mengalami kesulitan dalam belajar, waktu belajar siswa masih kurang, dan kurang minatnya siswa dalam membaca buku dan mengerjakan latihan soal. Dengan demikian dapat diketahui bahwa motivasi belajar siswa masih tergolong rendah.

Selain itu, penulis juga melakukan wawancara dengan teman sejawat mengenai proses pembelajaran daring. Hasilnya, guru belum menggunakan aplikasi pembelajaran yang bisa membantu proses pembelajaran daring. Padahal dengan penggunaan aplikasi pembelajaran berbasis daring inilah yang dapat mempermudah guru dalam kegiatan pembelajaran dan mempermudah siswa dalam belajar.

Menurut Uno (2011:23) motivasi belajar yaitu suatu dorongan internal dan eksternal pada siswa-siswa yang sedang belajar untuk mengadakan perubahan tingkah laku, pada umumnya dengan beberapa indikator atau unsur yang mendukung. Jadi, keseluruhan usaha dari dalam (internal) dan luar diri siswa (eksternal) yang dapat mendorong siswa untuk melakukan kegiatan belajar yang terarah, sehingga siswa dapat mencapai tujuan.

Dorongan internal dan eksternal pada siswa yang sedang belajar untuk mengadakan perubahan tingkah laku, pada umumnya dengan beberapa indikator atau unsur yang mendukung. Indikator motivasi belajar yang dikemukakan oleh Uno (2011:23), yaitu : adanya hasrat dan keinginan untuk berhasil, adanya dorongan dan kebutuhan dalam belajar, adanya harapan dan cita-cita masa depan, adanya penghargaan dalam belajar, adanya kegiatan yang menarik dalam belajar, adanya lingkungan belajar yang kondusif sehingga memungkinkan siswa dapat belajar dengan baik.

Hal yang dapat meningkatkan motivasi instrinsik antara lain dengan mengembangkan bakat atau keterampilan yang dimiliki siswa sesuai dengan bidang yang mereka kuasai, baik dalam bidang akademik maupun non-akademik. Sedangkan motivasi ekstrinsik timbul karena adanya rangsangan dari luar individu, misalnya dalam bidang pendidikan terdapat minat yang positif terhadap kegiatan pendidikan yang timbul karena melihat manfaatnya (Uno, 2011:4).

Oleh karena itu, penulis melakukan penelitian mengenai metode pembelajaran berbasis daring yaitu menggunakan platform Google Classroom. Hampir semua siswa memiliki Smartphone yang bisa mengakses platform Google Classroom. Hal ini bisa dimanfaatkan untuk menarik siswa dalam melaksanakan pembelajaran daring. Apalagi di era digital saat ini siswa lebih senang melihat Smartphone daripada melihat buku. Hal ini menjadi peluang untuk meningkatkan motivasi belajar siswa melalui platform Google Classroom. Penulis ingin mengetahui sejauh mana penggunaan Google Classroom dapat meningkatkan motivasi belajar siswa Tema 5 kelas VI SD Negeri 1 Purwanegara di masa Pandemi COVID-19. Tujuan penelitian ini adalah penggunaan Google Classroom dapat meningkatkan motivasi belajar siswa kelas VI Tema 5 SD Negeri 1 Purwanegara di Masa Pandemi. 
Berdasarkan uraian di atas, maka penulis membuat rancangan penelitian tindakan kelas dengan judul "PENGGUNAAN APLIKASI GOOGLE CLASSROOM DALAM MENINGKATKAN MOTIVASI BELAJAR SISWA KELAS VI TEMA 5 SD NEGERI 1 PURWANEGARA DI MASA PANDEMI". Dengan rancangan penelitian tindakan kelas ini diharapkan dapat membawa kebaikan bagi diri sendiri, lingkungan kerja, instansi, dan stakeholder

\section{METODE}

Jenis penelitian ini adalah penelitian tindakan kelas yang dilaksanakan dalam 3 siklus. Masing-masing siklus terdiri dari 1 kali pertemuan dan dilaksanakan sesuai dengan perubahan yang ingin dicapai menggunakan platform Google Classroom. Penelitian dilaksanakan pada semester I tahun pelajaran 2020/2021 dari bulan Oktober sampai November 2020. Survei awal pada tanggal 19 Oktober 2020, kemudian mengindentifikasi masalah dengan membuat action plan. Pelaksanaan Siklus Penelitian dari tanggal 19 Oktober sampai tanggal 13 November 2020. Data yang dianalisis berupa data kualitatif yaitu penggunaan Google Classroom. Teknik pengumpulan data menggunakan observasi dan angket. Uji validitas data menggunakan triangulasi teknik dan triangulasi sumber. Analisis data meliputi reduksi data, penyajian data, dan penarikan kesimpulan.

\section{HASIL DAN PEMBAHASAN}

Hasil kegiatan siklus I, siklus II, dan siklus III pada pembelajaran daring tema 5 dengan menggunakan Google Classroom adalah sebagai berikut :

Deskripsi Hasil Angket Motivasi Belajar Siswa

Tabel 1. Hasil Angket Motivasi Belajar Siswa Siklus I, II, dan III

\begin{tabular}{|c|c|c|c|c|}
\hline \multirow[t]{2}{*}{ No } & \multirow[t]{2}{*}{ Indikator / Pernyataan } & \multicolumn{3}{|c|}{ Prosentase } \\
\hline & & Siklus I & Siklus II & Siklus III \\
\hline 1. & Saya selalu belajar sendiri tanpa disuruh & $62,20 \%$ & $73,00 \%$ & $94,60 \%$ \\
\hline 2. & $\begin{array}{l}\text { Setiap hari saya belajar untuk menambah } \\
\text { pengetahuan }\end{array}$ & $78,40 \%$ & $94,60 \%$ & $97,30 \%$ \\
\hline 3. & $\begin{array}{l}\text { Ibu guru selalu memberikan pujian ketika } \\
\text { saya rajin mengerjakan tugas }\end{array}$ & $78,40 \%$ & $83,80 \%$ & $91,90 \%$ \\
\hline 4. & $\begin{array}{l}\text { Saya selalu berusaha mendapat nilai yang } \\
\text { baik karena mendapat hadiah dari orang } \\
\text { tua }\end{array}$ & $59,50 \%$ & $70,30 \%$ & $89,20 \%$ \\
\hline 5. & $\begin{array}{l}\text { Saya selalu senang belajar menggunakan } \\
\text { Google Classroom }\end{array}$ & $75,70 \%$ & $83,80 \%$ & $94,60 \%$ \\
\hline 6. & $\begin{array}{l}\text { PKn adalah pelajaran yang membosankan } \\
\text { karena banyak materi yang harus dipelajari } \\
\text { dan di hafal }\end{array}$ & $48,60 \%$ & $78,40 \%$ & $94,60 \%$ \\
\hline 7. & $\begin{array}{l}\text { Saat pelaksanaan Google Meet kelas saya } \\
\text { sangat diam dan tidak ada yang mau } \\
\text { bertanya }\end{array}$ & $40,50 \%$ & $83,80 \%$ & $100 \%$ \\
\hline 8. & $\begin{array}{l}\text { Pembelajaran daring menggunakan Google } \\
\text { Classroom menyenangkan sehingga } \\
\text { membuat saya semangat belajar }\end{array}$ & $56,80 \%$ & $81,10 \%$ & $97,30 \%$ \\
\hline
\end{tabular}


SHEs: Conference Series 3 (3) (2020) $256-261$

9. Saya tidak pernah memperhatikan guru dalam pembelajaran daring

10. Setiap ada kesulitan dalam memahami pelajaran saya selalu bertanya langsung kepada guru

11. Saya selalu paham terhadap materi yang sudah diajarkan guru

12. Saya senang melaksanakan pembelajaran daring mengunakan Google Classroom

13. Dengan adanya Google Form saya tidak pernah merasa bosan mengerjakan soal/tugas yang diberikan oleh guru

14. Saya senang membaca materi yang berkaitan dengan pembelajaran untuk pengetahuan melalui Google

15. Fitur Google Classroom mempermudah saya dalam melaksanakan pembelajaran daring

Rata-rata

\begin{tabular}{lll}
$59,50 \%$ & $91,90 \%$ & $97,30 \%$ \\
\hline $59,50 \%$ & $75,70 \%$ & $94,60 \%$ \\
\hline $67,60 \%$ & $91,90 \%$ & $97,30 \%$ \\
$73,00 \%$ & $81,10 \%$ & $94,60 \%$ \\
$75,60 \%$ & $86,50 \%$ & $97,30 \%$ \\
& & \\
$75,70 \%$ & $100,00 \%$ & $100,00 \%$ \\
\hline $64,90 \%$ & $86,50 \%$ & $91,90 \%$
\end{tabular}

$65 \%$

$84 \%$

$95 \%$

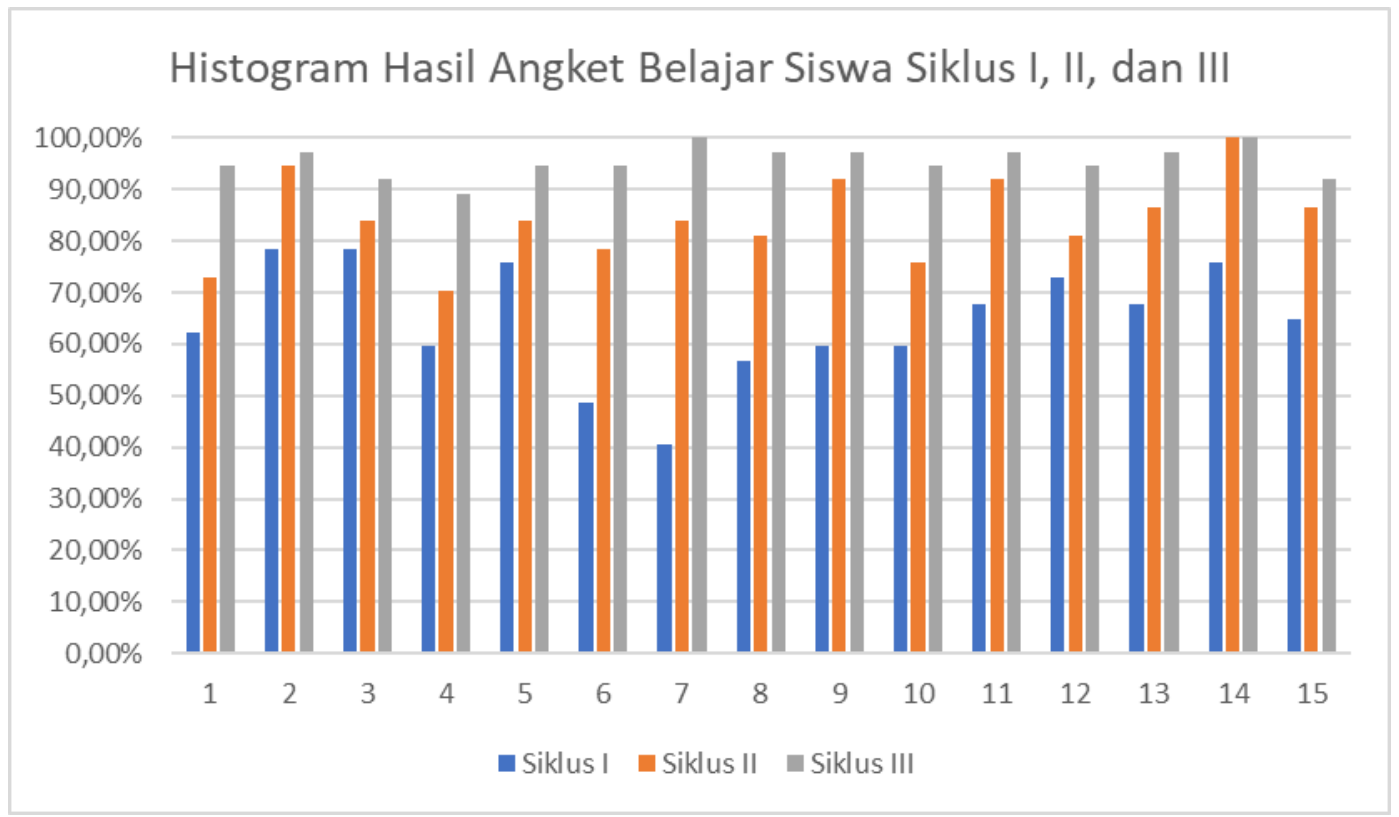

Gambar 1. Hasil Angket Motivasi Belajar Siswa Siklus I, II, dan III

Berdasarkan tabel 1 terlihat bahwa terjadi peningkatan rata-rata skor motivasi belajar siswa dari siklus I hingga siklus III. Pada siklus I rata-rata persentase motivasi siswa 65\% dengan kriteria tinggi, siklus II meningkat menjadi $84 \%$ dengan kriteria sangat tinggi, dan pada siklus III meningkat sangat pesat menjadi 95\% dengan kriteria sangat tinggi. Beberapa pernyataan yang mengalami peningkatan sangat pesat, yaitu saat pelaksanaan Google Meet kelas sangat diam dan tidak ada yang mau bertanya. Perolehan persentase pernyataan pada siklus I hanya mencapai $40,5 \%$, siklus II menjadi $83,8 \%$, dan pada siklus III mencapai $100 \%$. Peningkatan ini berkaitan dengan meningkatnya pemahaman siswa dalam beradaptasi dari pembelajaran daring yang minim komunikasi menjadi pembelajaran daring dengan tatap layer menggunakan 
Google Meet/Zoom. Proses adaptasi ini ternyata berkembang sangat pesat pada siswa sehingga keaktifan siswa dalam pembelajaran daring juga berkembang pesat. Siswa semakin percaya diri dalam melaksanakan pembelajaran daring dan tidak malu untuk bertanya. Keaktifan ini juga menandai antusiasme siswa yang tinggi dalam mengikuti pembelajaran daring.

Penggunaan platform Google Classroom ini ternyata dapat meningkatkan motivasi belajar siswa. Selama masa pandemic yang sudah berlangsung cukup lama membuat siswa merasa jenuh dengan kegiatan pembelajaran yang monoton. Ditambah lagi dengan minimnya komunikasi baik dengan guru maupun antar teman sehingga pembelajaran belum bisa dilaksanakan secara maksimal.

Peningkatan motivasi tidak hanya dapat dilihat pada angket motivasi saja, data lainnya yang mendukung antara lain observasi aktivitas siswa. Berdasarkan observasi aktivitas siswa terlihat adanya peningkatan aktivitas. Hasil pengamatan terhadap aktivitas siswa pada siklus I menunjukkan bahwa aktivitas siswa dalam pembelajaran sudah terlihat beberapa siswa yang terlihat aktif dan antusias, namun sebagian siswa lainnya masih kurang aktif dalam merespon pertanyaan yang diajukan guru. Hal ini terjadi karena siswa belum terbiasa melaksanakan pembelajaran daring menggunakan Google Meet/Zoom. Sehingga pada siklus III aktivitas siswa berkembang pesat dalam merespon pertanyaan dari guru dan berperan aktif mengeluarkan pendapatnya. Siswa sudah mulai terbiasa dengan pembelajaran daring dan merasa sangat antusia dengan kemampuan teknologi yang mereka miliki. Ketika motivasi meningkat maka akan mempengaruhi proses pembelajaran termasuk aktivitas, dengan peningkatan aktifitas tersebut dapat dikatakan bahwa motivasi siswa juga meningkat.

Data-data tersebut sudah cukup untuk membuat penelitian ini dikatakan berhasil untuk meningkatkan motivasi belajar siswa kelas VI SD Negeri 1 Purwanegara di masa Pandemi COVID-19.

Berdasarkan analisis motivasi belajar siswa setelah pelaksanaan tindakan, dapat diambil kesimpulan bahwa penggunaan Google Clasroom selama pembelajaran daring dapat meningkatkan motivasi belajar siswa Tema 5 Kelas 6 SD Negeri 1 Purwanegara. Hal ini sesuai dengan hasil penelitian yang dilakukan oleh Yuda Darmawan yang membuktikan bahwa penggunaan Google Classroom dapat meningkatkan motivasi belajar siswa Tema 5 Kelas VI secara signifikan. Hasil penelitian ini juga memperkuat pendapat Uno (2011:23) bahwa dorongan internal dan eksternal pada siswa yang sedang belajar berpengaruh pada proses pembelajaran sehingga motivasi belajar siswa meningkat secara signifikan.

\section{SIMPULAN}

Bagian Berdasarkan hasil penelitian dan uraian pembahasan maka dapat diambil simpulan sebagai berikut.

Pembelajaran daring menggunakan platform Google Classroom dapat meningkatkan motivasi belajar siswa kelas VI di SD Negeri 1 Purwanegara, hal ini didukung dengan adanya peningkatan aktivitas belajar siswa selama proses pembelajaran daring. Pada siklus I rata-rata persentase motivasi belajar siswa hanya mencapai $65 \%$ dengan kriteria tinggi, siklus II mencapai $84 \%$, dan siklus III meningkat pesat menjadi $95 \%$ dengan kriteria sangat tinggi.

Berdasarkan simpulan di atas, peneliti mengajukan rekomendasi ataupun saran agar motivasi belajar siswa terus meningkat, antara lain :

1. Pembelajaran daring menggunakan platform Google Classroom hendaknya dijadikan salah satu alternatif alat bantu pembelajaran yang digunakan oleh guru dalam upaya meningkatkan motivasi belajar siswa di masa Pandemi COVID-19.

2. Seorang pengajar hendaknya selalu menjadi motivator untuk anak didiknya sehingga mereka dapat menjadi pelajar yang baik dan menjadi manusia yang diharapkan sesuai tujuan pendidikan. 
3. Pelaksanaan pembelajaran hendaknya selalu diawali dengan menyampaikan tujuan pembelajaran dengan bahasa sederhana yang mudah dipahami oleh peserta didik sehingga mereka dapat mengetahui tujuan mereka dalam mempelajari suatu materi.

\section{DAFTAR PUSTAKA}

Arikunto, S., dkk. (2011). Penelitian Tindakan Kelas. Jakarta : P.T. Bumi Aksara.

Arikunto, Suhardjono dan Supardi. (2006). Penelitian Tindakan Kelas. Jakarta: Bumi Aksara.

Aqib, Zainal, dkk. (2011). Penelitian Tindakan Kelas untuk Guru SD, SLB, dan TK. Bandung: Yrama Widya.

Hopkins, David. (1993). A Teacher's Guide to Classroom Research. Philadelphia: Open University Press.

Mulyatiningsih, Endang. (2011). Metode Penelitian Terapan Bidang Pendidikan. Bandung: Alfabeta.

Padmono, Y. (2010). Kekurangan dan kelebihan, Manfaat Penerapan PTK. Online: edukasi.kompasiana.com.

Sardiman. (2011). Interaksi dan Motivasi Belajar Mengajar. Jakarta : P.T Raja Grafindo Persada.

Uno, Hamzah.B. (2011). Teori Motivasi dan Pengukurannya : Analisis Bidang Pendidikan. Jakarta : P.T. Bumi Aksara. 